\title{
Bioaugmentation of Soil Contaminated with Zinc
}

\author{
Rafal Strachel • Jadwiga Wyszkowska (iD) - Małgorzata \\ Baćmaga
}

Received: 23 September 2019 /Accepted: 6 August 2020 / Published online: 14 August 2020

(C) The Author(s) 2020

\begin{abstract}
An experiment described in this work aimed to establish the role of bioaugmentation in minimizing adverse outcomes of loamy sand contamination with zinc. The bioaugmentation was conducted with the use of microbial strains being most resistant to the action of zinc, which were isolated from the soil contaminated with $1250 \mathrm{mg} \mathrm{Zn}^{2+} \mathrm{kg}^{-1}$ dry matter (DM) of soil after 12-month incubation. The soil was inoculated with 4 strains of bacteria (Bacillus licheniformis KT986159.1, Bacillus sp. KF956639.1, Gordonia amicalis KM113029.1, Leifsonia sp. KJ191763.1) and 4 strains of fungi (Penicillium raperi KC797647.1, Penicillium janthinellum AY373921.1, Penicillium glabrum LT558918.1, Trichoderma harzianum LN714612.1). In the case of the non-contaminated soil, a metal dose of $250 \mathrm{mg} \mathrm{Zn}^{2+} \mathrm{kg}^{-1} \mathrm{DM}$ of soil contributed to enhanced proliferation and microorganisms and enzymatic activity. In turn, zinc in its highest dose $\left(1250 \mathrm{mg} \mathrm{Zn^{2+ }}\right.$ $\mathrm{kg}^{-1}$ DM of soil) evoked adverse effects, which were manifested in reduced numbers and diversity of microorganisms and suppressed activity of soil enzymes. This contamination rate stimulated only the proliferation of fungi, but their ecophysiological diversity was reduced either. The bioaugmentation treatment minimized adverse effects of zinc. Unfortunately, the use of autochthonous microorganisms failed to reduce zinc bioavailability in the soil.
\end{abstract}

R. Strachel $\cdot$ J. Wyszkowska $(\bowtie) \cdot$ M. Baćmaga Department of Microbiology, University of Warmia and Mazury in Olsztyn, Plac Łódzki 3, 10-727 Olsztyn, Poland e-mail: jadwiga.wyszkowska@uwm.edu.pl
Keywords Bioaugmentation $\cdot$ Soil enzymes $\cdot$ Soil microbiome $\cdot$ Zinc

\section{Introduction}

Growing contamination with heavy metals disturbs the functions of various elements of the natural environment, including soil. One of the adverse outcomes of the toxic action of trace elements is reduced soil fertility (Liu et al. 2018). Some heavy metals, i.e., $\mathrm{Zn}, \mathrm{Cu}, \mathrm{Ni}$, and $\mathrm{Mn}$, are indispensable for the proper functioning of live organisms. Nonetheless, most of them may impair cell metabolism (Selvi and Aruliah 2018). Effects of heavy metals on the microbiological and chemical properties of soil include decreased numbers and diversity of the microbiome and, consequently, the suppressed activity of soil enzymes (Cáliz et al. 2013; Qu et al. 2011; Strachel et al. 2018; Wyszkowska et al. 2016). For this reason, extensive works have been undertaken to develop methods that would minimize the adverse impact of heavy metals on the soil environment. Unlike organic contaminants, heavy metals are non-degradable (Alvarez et al. 2017); hence, remediation of soil contaminated by them involves their conversion into less toxic compounds or in their immobilization aimed at reducing their bioavailability. Physical methods of soil purification from heavy metals are costly and suitable only for small areas. In turn, chemical methods are rapid and more cost-effective but bear the risk of the release of other contaminants to the natural environment. Finally, biological methods are more time-consuming but 
environment-friendly, cost-effective, and suitable for large areas contaminated with heavy metals (Khalid et al. 2017).

Certain microbial species exhibit resistance to the action of such toxic substances as heavy metals, including zinc (Table 1). Their mechanisms of resistance to heavy metals include, e.g., the removal of ions from a cell, redox processes, cell wall structuring, and production of metallothioneins (Alvarez et al. 2017). These specific traits are increasingly often used in soil remediation; which involves the introduction of selected strains to the contaminated environment. Microorganisms used in bioaugmentation should be easy culturable, fastgrowing, and resistant to high concentrations of a contaminating substance (Mrozik and PiotrowskaSeget 2010).
Many research works have addressed the role of soil bioaugmentation in aiding phytoremediation by, e.g., production of specific compounds promoting plant development and heavy metal bioaccumulation (Khalid et al. 2017; Mesa et al. 2015; Ashraf et al. 2017; Ma et al. 2009; Navarro-Torre et al. 2017; Rojjanateeranaj et al. 2017). In turn, some other studies have reported on the feasibility of employing microorganisms to reduce heavy metal contents (Agnello et al. 2016; Babu et al. 2015; Emenike et al. 2017; Fauziah et al. 2017; Pani et al. 2017; Wang et al. 2014). Remediation exploiting microbial activity may be based on the biosorption or transformation of metals to unavailable forms (Cáliz et al. 2013). Nevertheless, little works can still be found on interactions between the introduced microorganisms and changes in the diversity of microorganisms in the soil.

Table 1 Microorganisms resistant to zinc

\begin{tabular}{|c|c|c|}
\hline Microorganisms & Pollutant & References \\
\hline Serratia marcescens & $\mathrm{Zn}$ & Selvi and Aruliah (2018) \\
\hline $\begin{array}{l}\text { Pseudomonas jessenii } \\
\text { Pseudomonas resinovorans } \\
\text { Rhodococcus erythropolis } \\
\text { Pseudomonas fluorescens } \\
\text { Bacillus cereus }\end{array}$ & $\mathrm{Zn}, \mathrm{Cr}, \mathrm{Ni}, \mathrm{Co}, \mathrm{Cd}, \mathrm{Cu}, \mathrm{Pb}$ & Alisi et al. (2009) \\
\hline $\begin{array}{l}\text { Bacillus sp. } \\
\text { Penicillium janthinellum } \\
\text { Trichoderma harzianum }\end{array}$ & $\mathrm{Zn}, \mathrm{Cu}, \mathrm{Ni}, \mathrm{Cd}$ & Chanda et al. (2017) \\
\hline $\begin{array}{l}\text { Pseudomonas alcaligenes } \\
\text { Pseudomonas mendocina } \\
\text { Bacillus pumilus } \\
\text { Ochrobactrum intermedium } \\
\text { Stenotrophomonas acidaminiphila }\end{array}$ & $\mathrm{Zn}, \mathrm{Pb}, \mathrm{Mn}, \mathrm{Hg}, \mathrm{Cu}, \mathrm{Cd}, \mathrm{Ni}, \mathrm{Cr}, \mathrm{Al}$ & Jayanthi et al. (2016) \\
\hline $\begin{array}{l}\text { Bacillus methylotrophicus } \\
\text { Bacillus aryabhattai } \\
\text { Bacillus aryabhattai } \\
\text { Bacillus licheniformis }\end{array}$ & $\mathrm{Zn}, \mathrm{Cu}, \mathrm{As}, \mathrm{Pb}$ & Mesa et al. (2015) \\
\hline $\begin{array}{l}\text { Arthrocnemum macrostachyum } \\
\text { Vibrio kanaloae } \\
\text { Pseudoalteromonas distinct } \\
\text { Pseudoalteromonas prydzensis } \\
\text { Staphylococcus warneri }\end{array}$ & $\mathrm{Zn}, \mathrm{As}, \mathrm{Cu}, \mathrm{Pb}$ & Navarro-Torre et al. (2016) \\
\hline $\begin{array}{l}\text { Pseudomonas fluorescens } \\
\text { Pseudomonas putida }\end{array}$ & $\mathrm{Zn}, \mathrm{Cu}, \mathrm{Cd}, \mathrm{Ni}$ & Płociniczak et al. (2013) \\
\hline
\end{tabular}


Even though zinc is one of the essential microelements taking part in vital processes of organisms, it may pose a threat to the soil environment, especially in excess amounts. This results, most of all, in the deteriorated quality of soil as a consequence of changes in soil microbiome and activity of soil enzymes (Boros et al. 2011; Wieczorek et al. 2015; Wieczorek et al. 2017; Wyszkowska et al. 2017). The deteriorating condition of the soil environment due to migration of contaminants of anthropogenic origin, including also zinc, has led to the search for novel and more effective solutions that would enable restoring the homeostasis of soil ecosystems. For this reason, a study was undertaken to evaluate the effectiveness of soil remediation with the bioaugmentation method in minimizing the adverse effect of zinc on the microbiological and biochemical properties of soil. Additional analyses were conducted to determine the effect of soil bioaugmentation with selected strains of microorganisms isolated from the soil after long-term exposure to zinc on the reduction of zinc bioavailability in the soil.

\section{Material and Methods}

\subsection{Soil Material}

The soil material used in the study had a granulometric composition of loamy sand with $\mathrm{pH}$ 5.6 and total organic carbon content of $-10.0 \mathrm{~g} \mathrm{~kg}^{-1}$ DM of soil. Its complete characteristics were provided in our previous work (Strachel et al. 2017). Loamy sand was selected for the study considering a high percentage of sandy soils in Poland (Bieganowski et al. 2013). The soil material was the source of autochthonous microorganisms isolated for the needs of the study and then was used in the assessment of bioaugmentation usability for minimizing adverse effects of soil contamination with zinc.

\subsubsection{Isolation of Microorganisms Resistant to the Effect of Zinc}

The soil material (100 g of air-dry soil) was transferred into glass beakers and contaminated with zinc. An aqueous solution of zinc $\left(\mathrm{ZnCl}_{2}\right)$ was added to beakers; at a

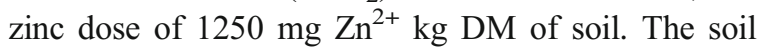
material was incubated at a temperature of $25{ }^{\circ} \mathrm{C}$ and brought to $50 \%$ of capillary water capacity. After
12 months, the soil samples were subjected to microbiological analyses. Growth of microorganisms was observed on the culture media for organotrophic bacteria (Bunt and Rovira 1955), yeast extract $1.0 \mathrm{~g}$; peptone $1.0 \mathrm{~g} ; \mathrm{KH}_{2} \mathrm{PO}_{4} 0.4 \mathrm{~g} ; \mathrm{CaCl}_{2} 0.1 \mathrm{~g}$; $\left(\mathrm{NH}_{4}\right)_{2} \mathrm{SO}_{4} 0.5 \mathrm{~g}$; $\mathrm{MgSO}_{4} \cdot 7 \mathrm{H}_{2} \mathrm{O} 0.5 \mathrm{~g}$; Mohr salt $0.03 \mathrm{~g}$; agar $20.0 \mathrm{~g}$; $\mathrm{MgCl}_{2} 0.2 \mathrm{~g} ; \mathrm{FeCl}_{2} 0.01 \mathrm{~g}$; soil extract $250 \mathrm{dm}^{3}$; and $\mathrm{H}_{2} \mathrm{O} 750 \mathrm{dm}^{3}$, and for fungi (Martin 1950), peptone $5 \mathrm{~g}$; $\mathrm{K}_{2} \mathrm{HPO}_{4} 1.0 \mathrm{~g}$; glucose $10 \mathrm{~g} ; \mathrm{MgSO}_{4} \cdot 7 \mathrm{H}_{2} \mathrm{O} 0.5 \mathrm{~g}$; agar $20.0 \mathrm{~g} ; \mathrm{H}_{2} \mathrm{O} 1 \mathrm{dm}^{3} ; 3.3 \mathrm{~cm}^{3}$ aqueous solution of Bengal rose $1 \% ; 25 \mathrm{~cm}^{3}$ aqueous solution of aureomycin $0.01 \%$; and $\mathrm{pH}$ 5.9. Biological material was sampled from the characteristic colonies and inoculated onto a culture medium appropriate for a given group of microorganisms. Reductive inoculations were conducted five times to achieve strains of desired purity.

\subsubsection{Identification of Microorganisms}

Microorganisms were identified based on the DNA sequence of the 16S rRNA subunit in the case of bacteria and of the ITS region in the case of fungi. The following primers were used in the PCR method for amplification of genetic material of bacteria, B-all For: GAG TTT GAT CCT GGC TCA G, and B-all Rev: ACG GCT ACC TTA CGA CTT, whereas the following primers were used in the case of fungi, ITS1: TTC GTA GGT GAA CCT GCG G and ITS4: TCC TCC GCT TAT TGA TAT GC. The isolation of the genomic DNA of microorganisms used for the bioaugmentation of soil contaminated with zinc was performed by the A\&A Biotechnology company (Poland), whereas the identification of microorganisms by the Macrogen company (The Netherlands). Genetic material was isolated according to the procedure described in the work by Baćmaga et al. (2015). The obtained DNA sequences of the bacterial 16S rRNA subunit were compared using the software available form BLAST database (Basic Local Alignment Search Tool). In turn, the ITS regions of fungi were compared with the use of Internal Transcribed Spacer software. Phylogenetic analysis of bacteria (Fig. 1) and fungi (Fig. 2) is performed using MEGA 7.0 software. An evolutionary distance matrix was calculated by using the Kimura two-parameter distance model, and a phylogenetic tree was reconstructed with the neighbor-joining method. The robustness of the tree was examined by the bootstrap analysis of 1000 replicates for bacterial strains and 500 replicates for fungal strains (Wang et al. 2011). 


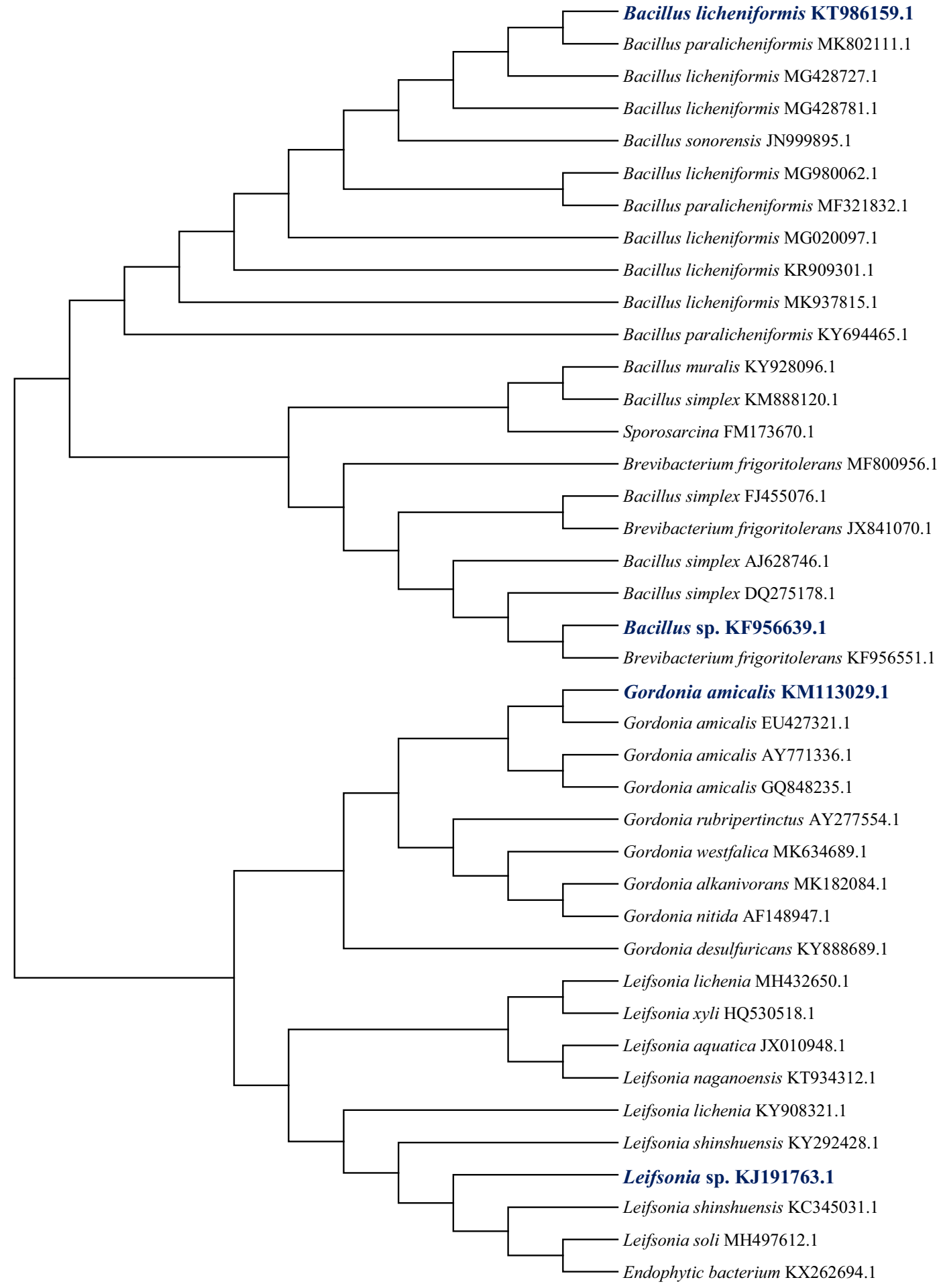

Fig. 1 Phylogenetic tree of bacterial strains, prepared based on the comparison of the 16S rRNA gene sequence by the neighborjoining method. Bootstrap values expressed as percentages of
1000 replications are given at branch points. Bar, 0.02 substitutions per nucleotide position. Bacterial strains used for soil bioaugmentation were indicated in navy blue color 


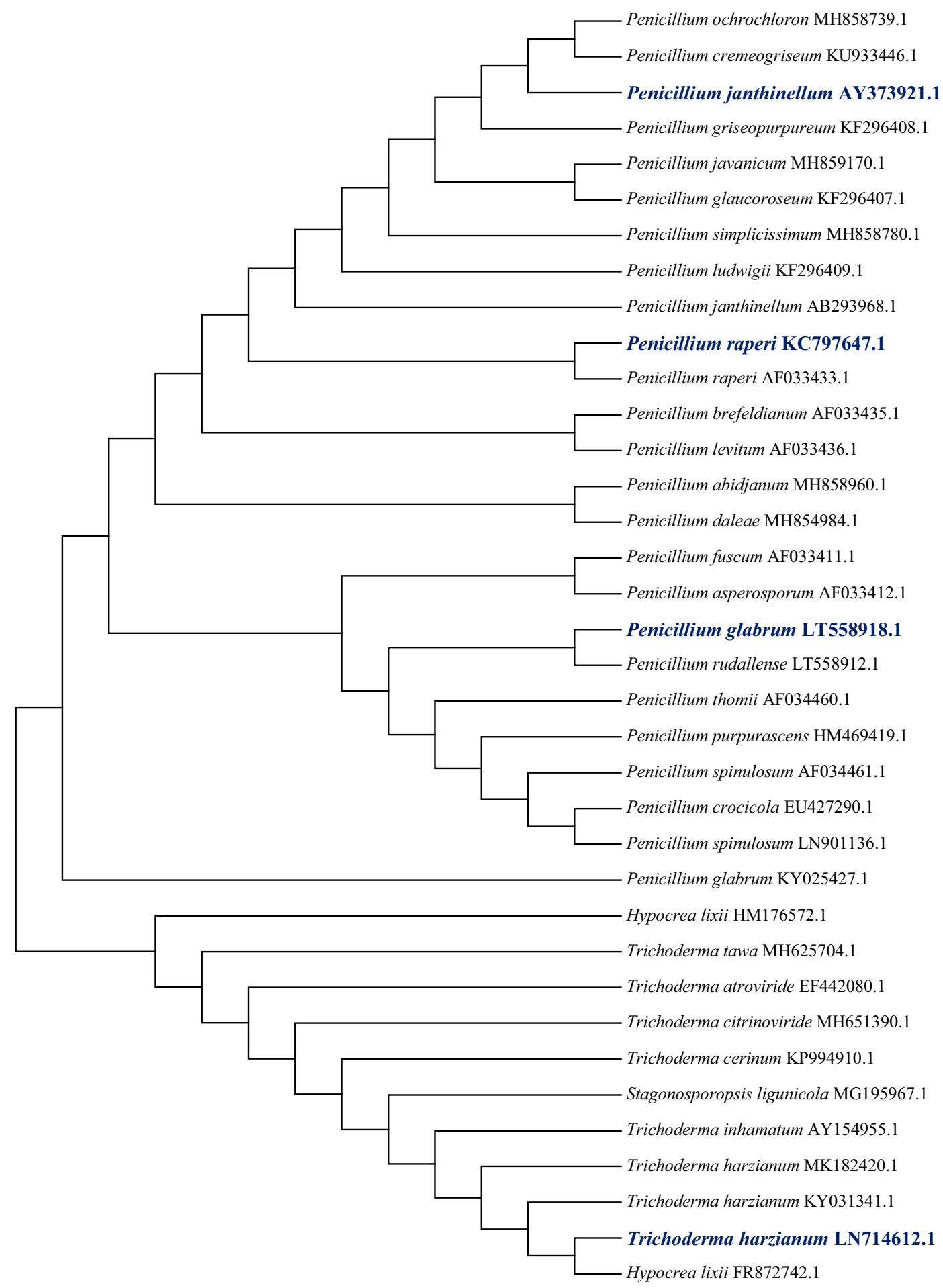

Fig. 2 Phylogenetic tree of fungal strains, prepared based on the comparison of the ITS region sequence by the neighbor-joining method. Bootstrap values expressed as percentages of 500 replications are given at branch points. Bar, 0.05 substitutions per nucleotide position. Fungal strains used for soil bioaugmentation were indicated in navy blue color 


\subsubsection{Soil Bioaugmentation}

The soil material was sieved through a screen with mesh size of $2 \mathrm{~mm}$. Then, $100 \mathrm{~g}$ samples of soil were weighed into glass beakers. The samples were prepared in 3 replications. Doses of zinc $\left(\mathrm{ZnCl}_{2}\right)$ added to beakers

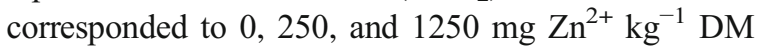
of soil. In respective combinations, $1 \mathrm{~cm}^{3}$ of the following media for the culture of microorganisms was added to soil in the liquid form: the culture medium for organotrophic bacteria (according to Bunt and Rovira 1955), the culture medium for fungi (according to Martin 1950), and a mixed culture medium for organotrophs and fungi. Subsequently, the soil samples were inoculated with a respective consortium of microorganisms by adding $1 \mathrm{~cm}^{3}$ of a suspension of microorganisms (which gave in total $10^{9}$ cells/spores of a microorganism per $1 \mathrm{~kg}$ DM of soil). The soil samples were thoroughly homogenized and incubated at a temperature of $25{ }^{\circ} \mathrm{C}$ for 2 to 20 weeks. Their moisture content was kept at $50 \%$ of the capillary water capacity (using sterile deionized water). Strains of microorganisms with $99 \%$ similarity of the nucleotide sequence of the 16S rRNA subunit (in the case of bacteria) and ITS region (in the case of fungi) were selected for bioaugmentation, which was conducted with the use of the following bacterial strains, Bacillus licheniformis KT986159.1, Bacillus sp. KF956639.1, Gordonia amicalis KM113029.1, and Leifsonia sp. KJ191763.1, and the following strains of fungi, Penicillium raperi KC797647.1, Penicillium janthinellum AY373921.1, Penicillium glabrum LT558918.1, and Trichoderma harzianum LN714612.1, used as inoculums. Each strain was multiplied on a liquid medium (with a composition identical as that of the control medium for bacteria and fungi) at a temperature of $28^{\circ} \mathrm{C}$ for 72 h (INE 200-800 incubator, Memmert Perfect). Afterward, cell number was determined according to the method of breed and the number of fungal spores using a Fuchs-Rosenthal chamber. Each inoculum (of bacteria or fungi) was composed of 4 species of microorganisms ( $25 \%$ of each strain). The following experimental variants were prepared: (1) control soil without any bacteria; (2) soil with the addition of bacteria consortium; (3) control soil for fungi; (4) soil with the addition of fungi consortium; (5) control soil for a mixture of bacteria and fungi; and (6) soil with the addition of a consortium of bacteria and fungi.

\subsubsection{Microbiological, Biochemical,} and Physicochemical Analyses

Analyses were conducted to determine numbers of the following groups of microorganisms: organotrophic bacteria, actinomycetes, and fungi. Colony growth was observed for 9 days to enable determining indices characterizing changes in the soil microbiome (microorganism colony development index and index of ecophysiological diversity of microorganisms). Biochemical analyses included the determination of activities of the following enzymes: dehydrogenases, catalase, acid phosphatase, alkaline phosphatase, urease, and $\beta$-glucosidase. The microbiological and biochemical analyses were conducted according to methods described in the work by Borowik et al. (2017). The soil samples were also determined for the content of available zinc with the method of flame atomic absorption spectrometry (FAAS) (Harris 2006).

\subsubsection{Computation of Indices and Statistical Analysis}

The growth rate of the analyzed groups of microorganisms was used to compute the colony development (CD) index according to the formula provided by Sarathchandra et al. (1997) and the index of ecophysiological diversity (EP) of microorganisms based on the formula provided by De Leij et al. (1993). In turn, determining the enzymatic activity allowed calculating the biochemical index of soil quality (BA), according to Wyszkowska et al. (2013).

Results of analyses were subjected to statistical analysis in Statistica 12.0 software (StatSoft Inc. 2014) at a significance level of $p=0.01$. The percentage involvement of factors of the observed variability was computed using the $\eta^{2}$ index. Principal component analysis (PCA) was conducted for microbial counts and enzymatic activity. Homogenous groups were distinguished based on Tukey's HSD test.

\section{Results and Discussion}

\subsection{Changes in Microbiological Properties of Soil}

Soil contamination with zinc had a significant effect on changes in the counts of microorganisms (Fig. 3). Among the analyzed groups of the soil microbiome, zinc had the strongest impact on the number of fungi, 
Fig. 3 Percentage of components of the observed variability $\left(\eta^{2}\right)$ after bioaugmentation with the use of bacterial inoculum (A), fungal inoculum (B), and inoculum of bacteria and fungi (C). a dose of $\mathrm{Zn}^{2+}$, b inoculum, c incubation time; Org

organotrophic bacteria, Act actinomycetes, Fun fungi, Deh dehydrogenases, Cat catalase, Pac acid phosphatase, Pal alkaline phosphatase, Ure urease, Glu $\beta$ glucosidase
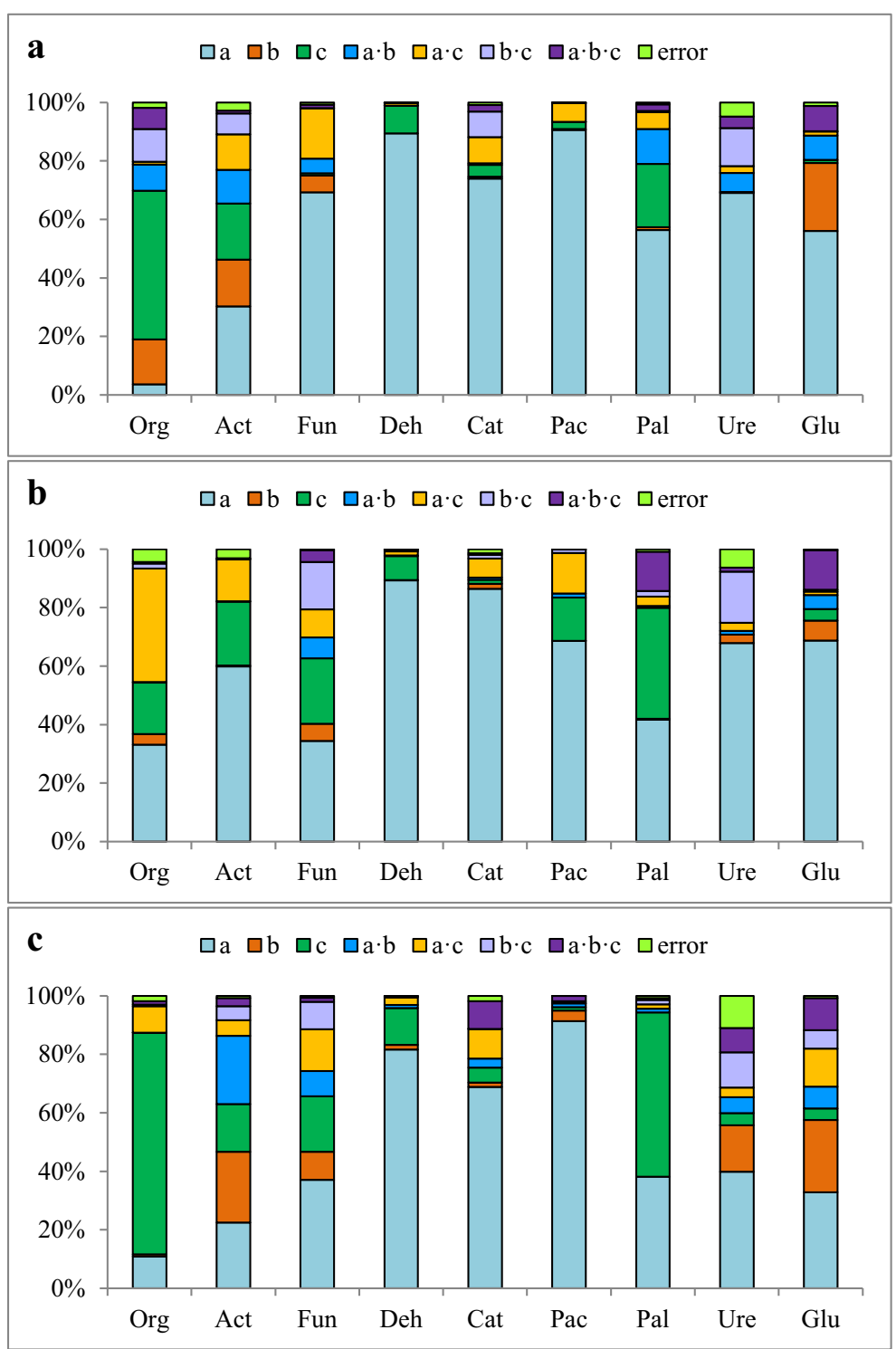

except for the variant with soil bioaugmentation using fungal strains, when it caused $59.85 \%$ in the proliferation of actinomycetes. Zinc had also a significant influence on the organotrophic bacteria, but not after soil incubation with the bacterial inoculum and a mixture of bacteria and fungi. In these two variants (inoculum of bacteria and inoculum of bacteria and fungi), their count was largely dependent on soil incubation time by $50.81 \%$ and $75.79 \%$, respectively).

Considering microbial counts, it may be concluded that the response of fungi to soil contamination with zinc differed compared with that of the other groups of microorganisms (Fig. 4). A zinc dose of $1250 \mathrm{mg} \mathrm{Zn^{2+ }}$ $\mathrm{kg}^{-1}$ stimulated fungi proliferation but had an inhibiting effect on the development of organotrophic bacteria and actinomycetes. These dependencies are confirmed in Fig. 4 by cases located around vectors describing these groups of microorganisms. Importantly, in the variants with $250 \mathrm{mg} \mathrm{Zn}^{2+} \mathrm{kg}^{-1}$, the numbers of bacteria and actinomycetes increased after soil inoculation with the consortium of bacteria, as observed in the second week of the experiment. Soil contamination with zinc may upset the homeostasis of its microbiome (Strachel et al. 2017; Wyszkowska et al. 2013; Wyszkowska et al. 2016), which is manifested by a stimulated proliferation of microorganisms caused by small amounts of zinc or 


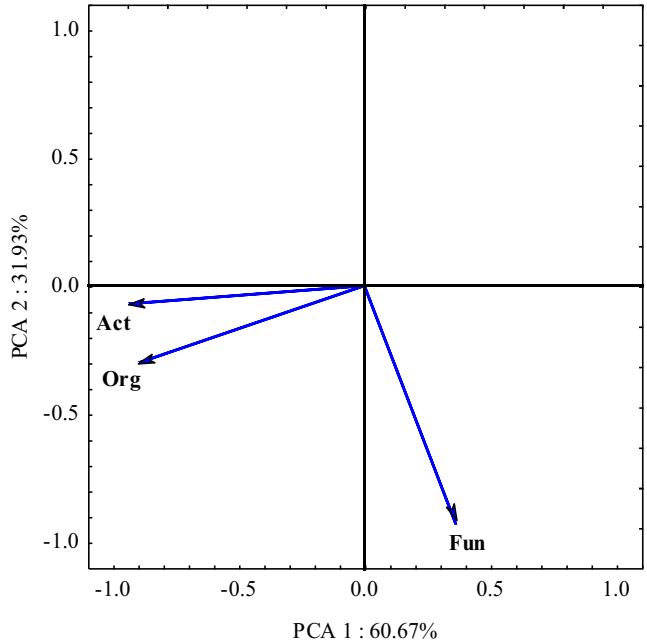

Fig. 4 Microbe numbers in zinc-contaminated soil subjected to bioaugmentation (PCA). Org organotrophic bacteria, Act actinomycetes, Fun fungi. A control soil for bacteria, B soil inoculated with the consortium of bacteria, $\mathrm{C}$ control soil for mold fungi, D soil inoculated with the consortium of mold fungi, E control soil

by the toxic effect of caused by the severe soil contamination with this metal. The adverse impact of zinc may be mitigated by bioaugmentation, which may increase counts of microorganisms (Babu et al. 2015).

The analysis of the growth rate of microorganisms enables concluding that the investigated species of fungi were the fast-growing ones (r-strategists) (Fig. 5). Their development was the most intense in the first 3 days. Also the organotrophic bacteria were intensively developing in the first days, but their slowly growing species could be observed as well. In turn, the development of actinomycetes was the most stable in time. In the case of organotrophs and actinomycetes, the long-term (20 weeks) exposure to $1250 \mathrm{mg} \mathrm{Zn}^{2+}$ caused a significant increase in their CD index value compared with the non-contaminated soil. In the 20th week of the experiment, the value of the $\mathrm{CD}$ index computed for organotrophic bacteria after soil contamination with this dose of zinc ranged from 15.73 (soil inoculated with the consortium of fungi) to 18.87 (soil inoculated with the consortium of bacteria and fungi). In contrast, the value of the CD index computed for actinomycetes ranged from 11.45 (control soil) to 16.60 (soil inoculated with the consortium of bacteria). This may be indicative of the inhibited development of rapidly growing microorganisms and the promoted development of the slowly growing ones. An opposite dependency was observed in the 20th week for fungi, except for the variants in which soil was inoculated with the consortium of fungi and with the consortium of bacteria and fungi, when the value of the $\mathrm{CD}$ index decreased from 32.06 to 30.03 , as well as from 32.76 to 26.54 , respectively. The development of microorganisms tolerant to soil contamination with heavy metals may be associated with a few mechanisms, including, e.g., decreased permeability of cell walls, active transport and sequestration of metal in a cell, enzymatic conversion of a metal to a less toxic form, and extracellular binding of metals as a result of the production of polymeric substances which reduce metal mobility (Ashraf et al. 2017; Ojuederie and Babalola 2017). Important are also interactions between individual species of microorganisms. For instance, in a study by Agnello et al. (2016), the bioaugmentation caused a higher number of heterotrophic bacteria, which was due to the high competition of the strains used with autochthonous microorganisms.

In the present study, the values of the ecophysiological (EP) diversity index range from 0.10 to 0.47 for actinomycetes, from 0.13 to 0.41 for organotrophic bacteria, and from 0.01 to 0.32 for fungi and are the highest in the case of actinomycetes (Fig. 6). After 20 weeks of incubation of the non-contaminated soil, the EP value calculated for organotrophic bacteria was lower than after 2 weeks of incubation. The EP index 

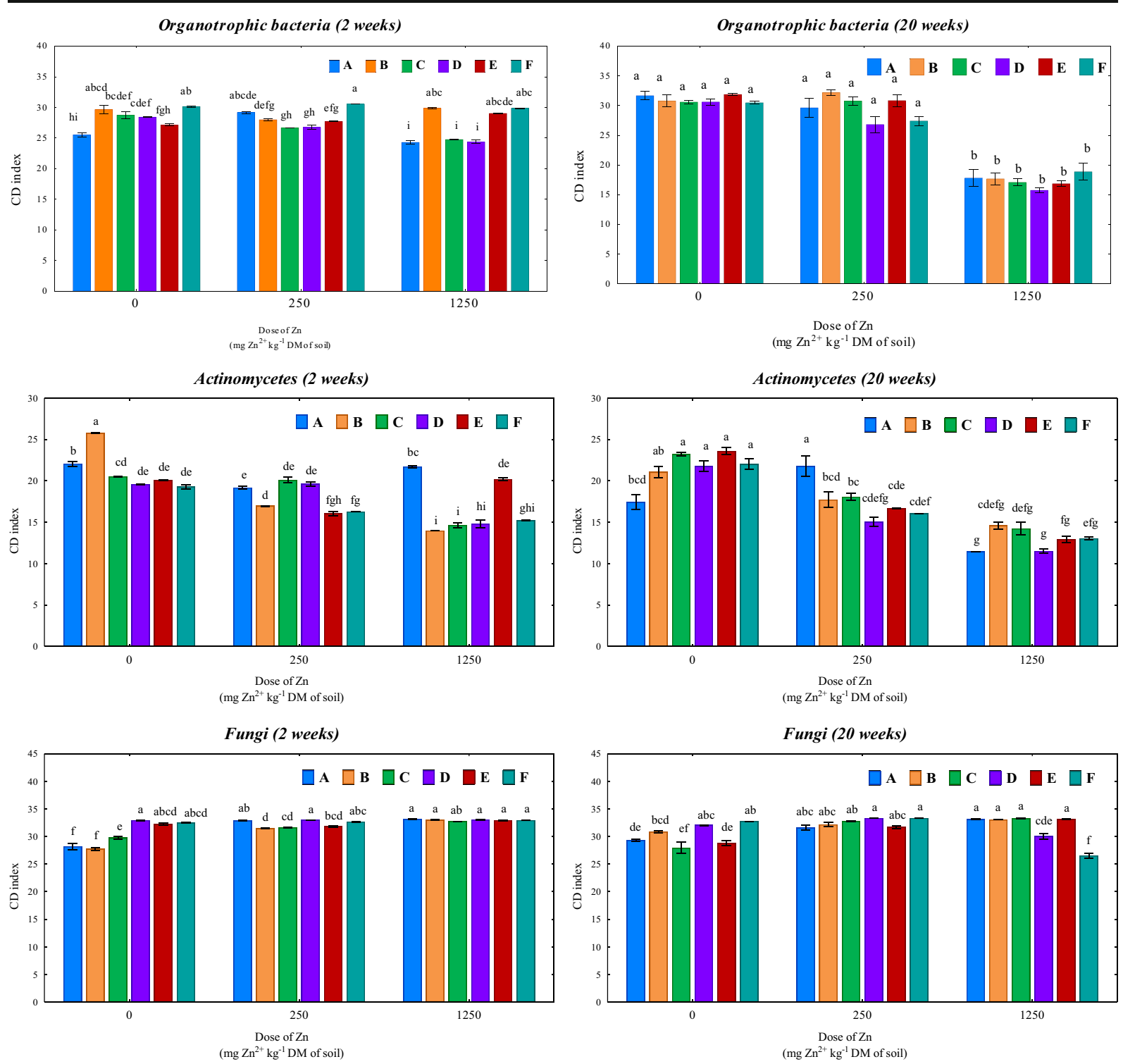

Fig. 5 Effect of soil bioaugmentation on microorganism colony development (CD) index. A control soil for bacteria, B soil inoculated with the consortium of bacteria, $\mathrm{C}$ control soil for mold fungi, D soil inoculated with the consortium of mold fungi, E control soil for bacteria and mold fungi, F soil inoculated with the

value decreased in the range from 8.00 (soil inoculated with the consortium of bacteria and fungi) to $61.11 \%$ (control soil without bacteria). Contamination with zinc contributed to changes in the ecophysiological diversity of the soil environment. Diminished microbiome diversity under exposure to heavy metals was also observed by Fauziah et al. (2017). Soil contamination with zinc significantly decreased the value of the EP index of fungi in the 2 nd and 20th week of the experiment,

consortium of bacteria and mold fungi. Homogenous groups (a-i) were formed separately for each group of microorganisms in the 2nd and 20th week of soil incubation $(p=0.01)$. Whiskers in columns indicate standard error

especially after soil exposure to $1250 \mathrm{mg} \mathrm{Zn}^{2+}$ $\mathrm{kg}^{-1}$. However, after 20 weeks of incubation of the soil exposed to this dose of zinc, soil bioaugmentation with the consortium of fungi and with the consortium of bacteria and fungi contributed to the EP index increase. When referring these data to the earlier observations regarding the stimulating effect of zinc on fungi multiplication, they may indicate the development of species resistant to this metal. 

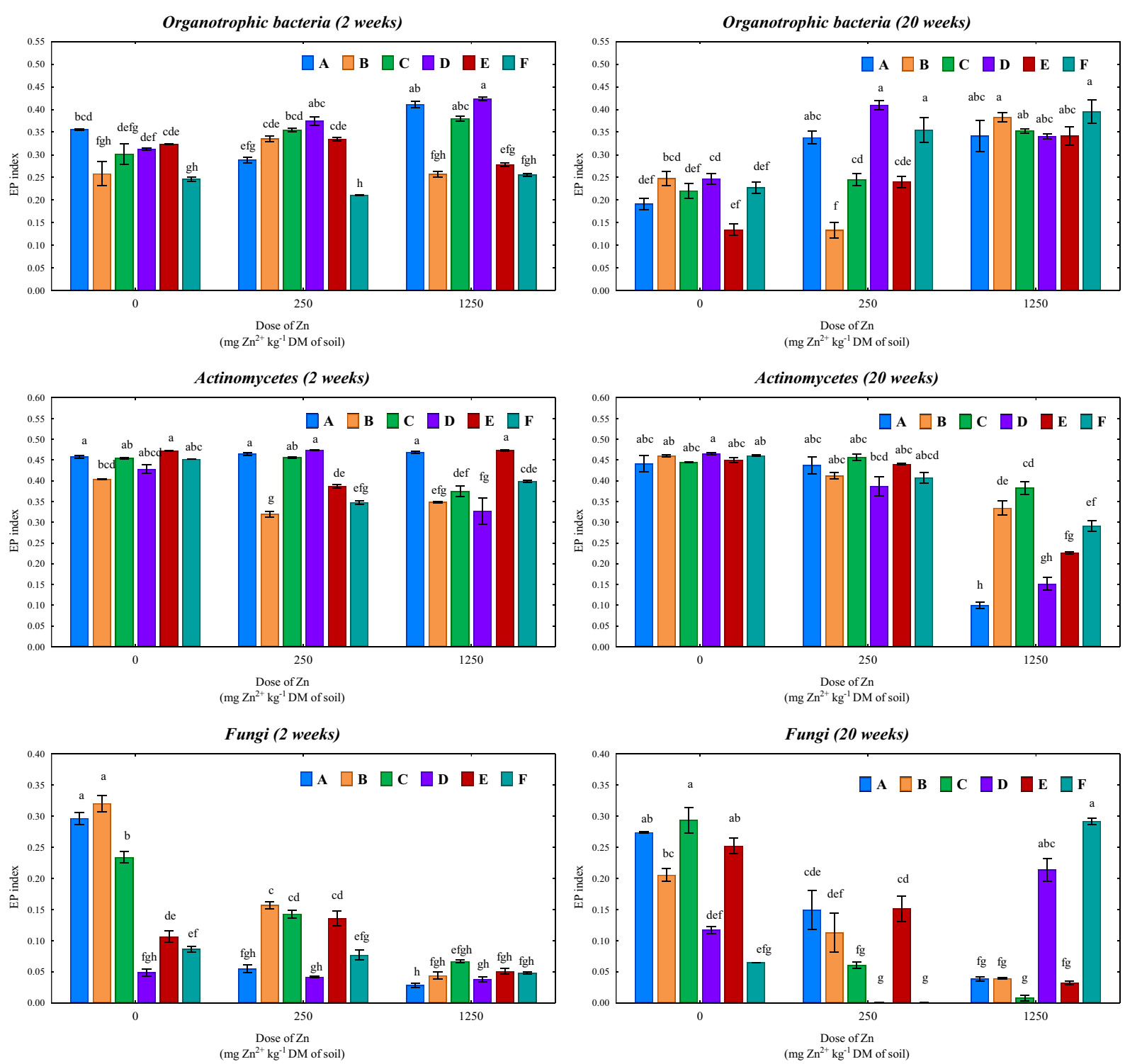

Fig. 6 Effect of soil bioaugmentation on the ecophysiological (EP) diversity index of microorganisms. A control soil for bacteria, $\mathrm{B}$ soil inoculated with the consortium of bacteria, $\mathrm{C}$ control soil for mold fungi, D soil inoculated with the consortium of mold fungi, $\mathrm{E}$ control soil for bacteria and mold fungi, $\mathrm{F}$ soil inoculated with the

consortium of bacteria and mold fungi. Homogenous groups $(\mathrm{a}-\mathrm{h})$ were formed separately for each group of microorganisms in the 2nd and 20th week of soil incubation $(p=0.01)$. Whiskers in columns indicate standard error

After 20 weeks of incubation of the most contaminated soil (1250 $\mathrm{mg} \mathrm{Zn}^{2+}$ ), its bioaugmentation with bacterial strains caused an increase in the EP value computed for actinomycetes, in contrast to the fungi inoculum which decreased its value. In turn, the consortium of bacteria and fungi had a positive effect on the ecophysiological diversity of all groups of microorganisms tested. A study

conducted by Wang et al. (2014) has suggested that the microbiological diversity of soil is largely dependent on conditions of microorganism inoculation. The introduced strains have greater chances for development and activity upon the use of an additive rich in nutrients. This may result in the enhanced multiplication of both the introduced strain and the autochthonous microorganisms. 


\subsection{Changes in the Biochemical Properties of Soil}

Changes in activities of the soil enzymes analyzed are affected to the greatest extent by zinc dose (Fig. 3). However, alkaline phosphatase activity was also significantly influenced by the soil incubation time, with the most significant effect observed in the soil inoculated with the consortium of bacteria and fungi. In turn, soil inoculation with the consortium of microorganisms had the most substantial effect on the activity of $\beta$-glucosidase, by $6.84 \%$ (the consortium of fungi) to $24.76 \%$ (the consortium of bacteria and fungi).

Soil contamination with $1250 \mathrm{mg} \mathrm{Zn}{ }^{2+} \mathrm{kg}^{-1} \mathrm{DM}$ of soil suppresses activities of the enzymes tested (Fig. 7). Such observations were also made by other authors (Borowik et al. 2014; Kucharski et al. 2011; Strachel et al. 2017; Wieczorek et al. 2014; Wyszkowska et al. 2016). Based on the arrangement of vectors describing biochemical properties of soil in Fig. 7, dehydrogenases, catalase, and acid phosphatase respond similarly to the analyzed factors, and their highest activities are determined in the non-contaminated soil. In a research conducted by Agnello et al. (2016), bioaugmentation enhanced the activity of lipase, whereas in the study carried out by Babu et al. (2015), soil inoculation with Pseudomonas koreensis AGB-1 strain (resistant to zinc contamination) contributed to the enhanced activities of dehydrogenases (by 42\%) and acid phosphatase (by $32 \%$ ). Urease and alkaline phosphatase responded similarly to changes in the soil environment; their activities were stimulated by a zinc dose of $250 \mathrm{mg} \mathrm{Zn}^{2+} \mathrm{kg}^{-1} \mathrm{DM}$ of soil. This effect was additionally intensified by soil inoculation with the consortium of bacteria and fungi. The response of $\beta$-glucosidase was opposite to the other enzymes tested and manifested by its promoted activity after soil contamination with $250 \mathrm{mg}$ $\mathrm{Zn}^{2+} \mathrm{kg}^{-1} \mathrm{DM}$ of soil and its inoculation with the consortium of fungi. This is indicative of a strong correlation between fungi count and activity of $\beta$ glucosidase. As reported by Sørensen et al. (2013), fungi are producers of many lignocellulosic enzymes, including $\beta$-glucosidase.

The responses of individual enzymes to the experimental factors may differ. Nevertheless, the biochemical properties of soil are indicative of its fertility. Enzymes are responsible for the rate of metabolic transformations, including nutrients availability. The soil fertility index (BA), proposed by Wyszkowska et al. (2013), is based on the total activity of a few enzymes, due to which it may, in a simple way, depict the overall condition of the soil environment. In the conducted experiment, we observe a toxic effect of soil contamination with zinc, which was confirmed by the computed value of the

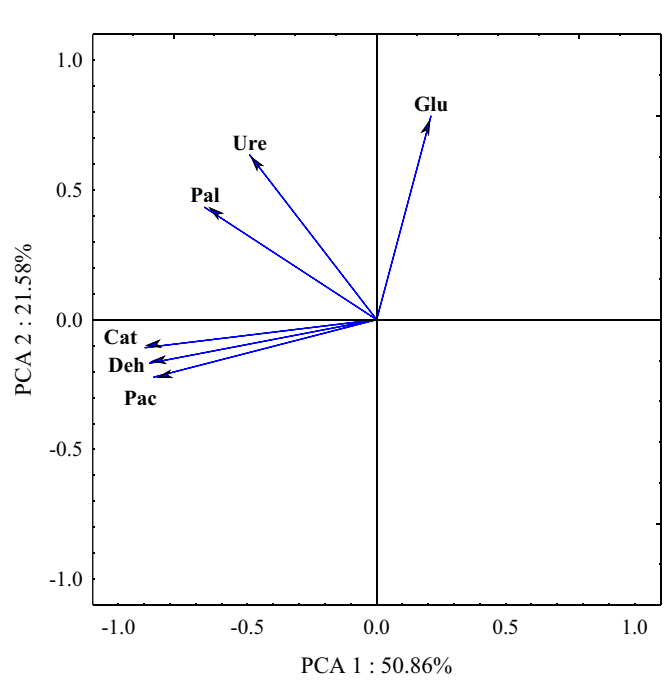

Fig. 7 Activity of enzymes in zinc-contaminated soil subjected to bioaugmentation (PCA). Deh dehydrogenases, Cat catalase, Pac acid phosphatase, Pal alkaline phosphatase, Ure urease, Glu $\beta$ glucosidase. A control soil for bacteria, $\mathrm{B}$ soil inoculated with the consortium of bacteria, C control soil for mold fungi, D soil

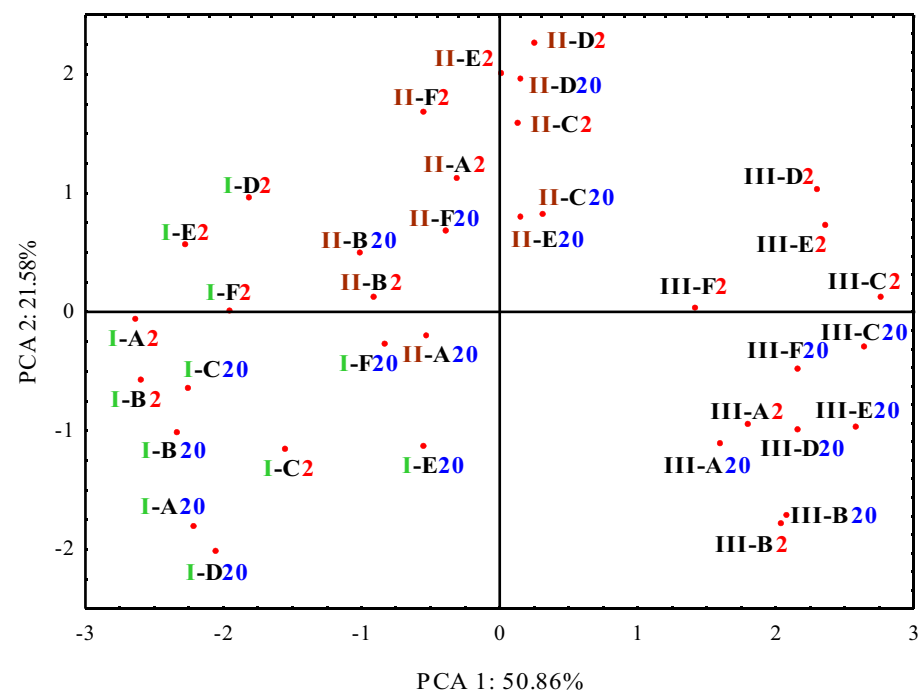

inoculated with the consortium of mold fungi, E control soil for bacteria and mold fungi, F soil inoculated with the consortium of bacteria and mold fungi. Zinc dose: I soil without zinc addition, II $250 \mathrm{mg} \mathrm{Zn}^{2+} \mathrm{kg}^{-1} \mathrm{DM}$ of soil, III $1250 \mathrm{mg} \mathrm{Zn}^{2+} \mathrm{kg}^{-1} \mathrm{DM}$ of soil. Soil incubation time: 2-2 weeks, 20-20 weeks 
BA index (Fig. 8). The longer exposure time (20 weeks) to experimental factors contributed to its increased value. In this period, the BA ranged from 1.29 (soil contaminated with $1250 \mathrm{mg} \mathrm{Zn}^{2+}$ $\mathrm{kg}^{-1}$ and inoculated with the consortium of bacteria and fungi) to 7.91 (non-contaminated soil, inoculated with the consortium of fungi). This may point to the effect of time on microbiological balance stabilization in the zinc-stressed soil. After 2 weeks since the inoculation of the bacterial consortium to the soil contaminated with $250 \mathrm{mg} \mathrm{Zn}{ }^{2+} \mathrm{kg}^{-1} \mathrm{DM}$ of soil, the value of the BA index was observed to increase (by $6.76 \%$ compared with the control soil for bacteria). Its increase was also noted in the soil contaminated with $1250 \mathrm{mg} \mathrm{Zn}^{2+} \mathrm{kg}^{-1} \mathrm{DM}$ of soil and inoculated with the consortium of fungi (increase by $11.81 \%$ compared with the control soil for fungi) and with the consortium of bacteria and fungi (increase by $9.70 \%$ compared with the control soil for bacteria and fungi). In the 20th week of the experiment, an increase in BA value was determined in the non-contaminated soil inoculated with the consortium of bacteria and fungi and in the soil con-

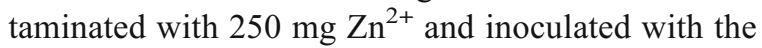
consortium of fungi strains.

\subsection{Changes in Zinc Content in the Soil}

The bioaugmentation treatment generally had no significant effect on the content of available zinc in the soil (Table 2). Some regularity was observed in the case of soil inoculation with fungi, which after 20 weeks of soil incubation reduced zinc absorption. As reported by Emenike et al. (2017), autochthonous microorganisms are capable of "cleaning" the soil from heavy metals. However, as underlined by these authors, under severe soil contamination with heavy metals, the process of reducing their availability should be aided by bioaugmentation with strains resistant to the effects of these metals. Changes in the solubility of heavy metals in the soil induced by microorganisms depend mainly on the strains used for soil inoculation. A study conducted by Braud et al. (2006) demonstrated both an increase and a decrease in metal availability, as affected by the introduced strain of microorganisms. Immobilization of heavy metals prevents their migration in a soil solution, thereby reducing contamination of larger soil areas (Valentine et al. 1996).

Some of the strains used in our study were also investigated by other authors for their effect on changes in the availability of heavy metals: T. harzianum
Fig. 8 Effect of bioaugmentation on the index of biochemical quality of soil (BA) after 2 weeks and 20 weeks of incubation. A control soil for bacteria, B soil inoculated with the consortium of bacteria, $\mathrm{C}$ control soil for mold fungi, D soil inoculated with the consortium of mold fungi, E control soil for bacteria and mold fungi, F soil inoculated with the consortium of bacteria and mold fungi. Homogenous groups $(\mathrm{a}-\mathrm{k})$ were formed separately for each group of microorganisms in 2nd and 20th week of soil incubation $(p=0.01)$. Whiskers in columns indicate standard error
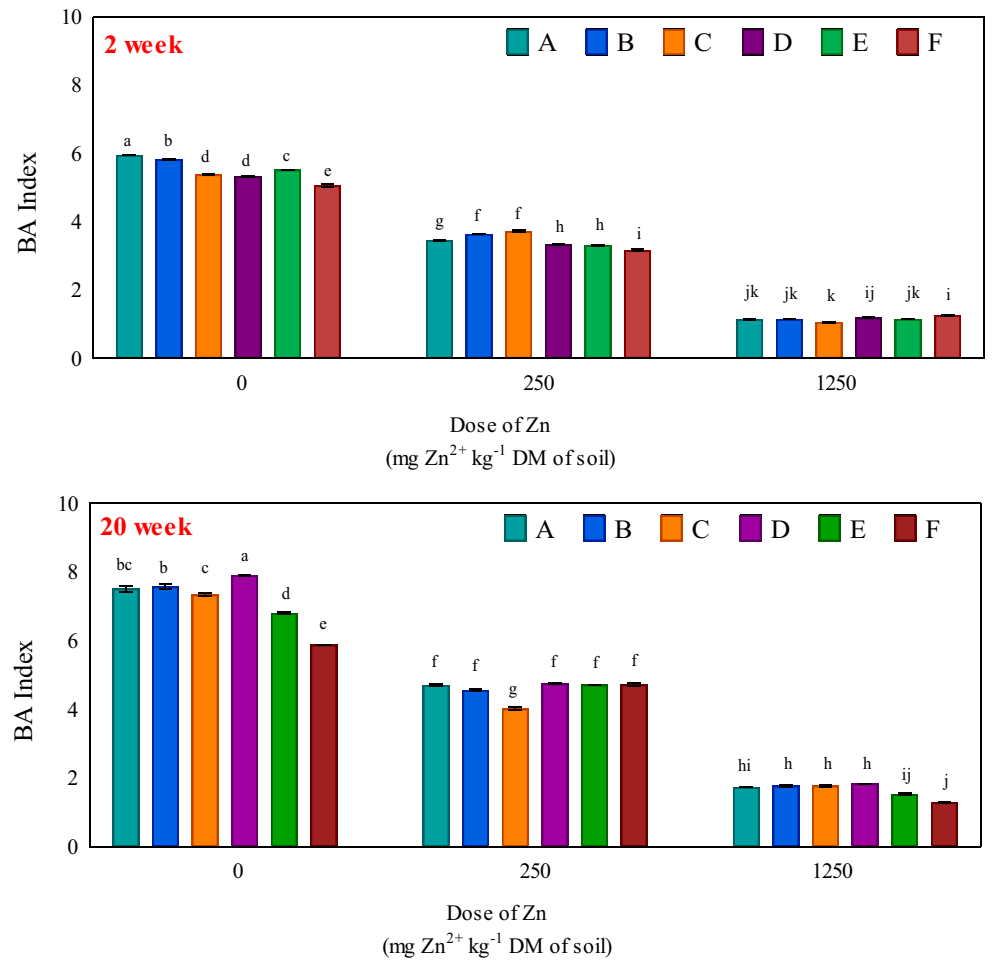
Table 2 Content of available zinc (in $\mathrm{mg} \mathrm{kg}^{-1} \mathrm{DM}$ of soil)

\begin{tabular}{|c|c|c|c|c|c|c|}
\hline \multirow{3}{*}{$\begin{array}{l}\mathrm{mg} \mathrm{Zn}^{2+} \mathrm{kg}^{-1} \\
\text { DM of soil }\end{array}$} & \multicolumn{6}{|c|}{ Type of inoculum } \\
\hline & \multicolumn{2}{|l|}{ Bacteria } & \multicolumn{2}{|l|}{ Fungi } & \multicolumn{2}{|c|}{ Bacteria and Fungi } \\
\hline & Control & Inoculum & Control & Inoculum & Control & Inoculum \\
\hline \multicolumn{7}{|l|}{2 weeks } \\
\hline 0 & 7.2 & 7.9 & 7.2 & 6.8 & 6.8 & 6.9 \\
\hline 250 & 243.0 & 236.0 & 241.0 & 242.0 & 242.0 & 247.3 \\
\hline 1250 & 1132.0 & 1156.0 & 1116.0 & 1230.0 & 1225.0 & 1209.9 \\
\hline \multicolumn{7}{|l|}{20 weeks } \\
\hline 0 & 4.7 & 5.9 & 5.5 & 5.3 & 5.5 & 6.5 \\
\hline 250 & 241.3 & 231.3 & 241.5 & 217.3 & 235.0 & 232.8 \\
\hline 1250 & 1272.0 & 1167.0 & 1147.0 & 1021.0 & 1327.0 & 1220.0 \\
\hline
\end{tabular}

(Hoseinzadeh et al. 2017; Krantz-Rülcker et al. 1993), $P$. janthinellum ( $\mathrm{Su}$ et al. 2010), and B. licheniformis (Hafez et al. 2002; Mesa et al. 2015; Zhou et al. 2007). In the experiment conducted by Krantz-Rülcker et al. (1993), Zn availability reduction by T. harzianum was associated with the formation of complexing compounds. Metals may be bound both on the surface and inside cells of microorganisms ( $\mathrm{Su}$ et al. 2010). Biosorption is based on the interactions of ions with functional groups of a cell wall (Das 2010). The cell wall structure determines the effectiveness of heavy metal ion binding by bacterial cells. In the Grampositive bacteria, a strong effect is ascribed to a peptidoglycan, while in the Gram-negative ones to a lipopolysaccharide. These structures of the cell wall are the active sites of heavy metal binding by bacteria because they act as ligands (Gupta et al. 2015). Gupta and Diwan (2017) have reported the capability of bacterial to bioaccumulate heavy metal ions in a cell to be associated with the presence of an exopolysaccharide, the chemical structure of which allows for the non-specific binding of these elements. The protective action of exopolysaccharides against the adverse effects of heavy metal ions has been reported in such bacteria as Alcaligenes faecalis, Xanthomonas campestris, and Acetobacter xylinum (Donot et al. 2012). The capability for heavy metal ion biosorption has also been demonstrated by Saccharomyces cerevisiae yeast, but in their case, the biosorption proceeds via the mechanism of ion scavenging (Machado et al. 2010). In turn, increased metal mobility is linked with the production of biosurfactants, organic acids, and siderophores (Ma et al. 2009). An excellent example, in this case, may be $B$. licheniformis, which is capable of producing biosurfactants (Simpson et al. 2011). In turn, Desulfovibrio desulfuricans converts sulfate into bisulfate, which reacts with ions of heavy metals, forming insoluble forms of metal sulfides (Chibuike and Obiora 2014). A change in solubility may also be caused by changes in environment $\mathrm{pH}$ (Babu et al. 2015). However, it is difficult to predict the effect of the treatments applied in complex systems like, e.g., soil. In the present study, soil inoculation with the autochthonous strains resistant to zinc did not reduce its bioavailability.

\section{Conclusions}

Results of the conducted experiment demonstrated that zinc applied in the dose of $1250 \mathrm{mg} \mathrm{Zn}^{2+} \mathrm{kg}^{-1} \mathrm{DM}$ of soil had an adverse effect on microbiological and biochemical parameters of loamy sand. However, its dose of $250 \mathrm{mg} \mathrm{Zn}^{2+} \mathrm{kg}^{-1} \mathrm{DM}$ of soil was shown to stimulate the proliferation of microorganisms and to enhance the activity of selected enzymes. Soil inoculation with the selected zinc-resistant autochthonous microorganisms contributed to the alleviation of the adverse effects evoked by soil contamination with this heavy metal. This was associated with the upset microbiological and biochemical homeostasis of the soil. Even though microorganisms are capable of reducing the availability of heavy metals in the soil, the consortia of microorganisms used in our experiment failed to bring the expected effect, i.e., did not reduce zinc bioavailability. 
Funding Information The research was conducted within the statutory activity supported by the Ministry of Science and Higher Education.

\section{Compliance with Ethical Standards}

Conflict of Interest The authors have declared no conflict of interest.

Open Access This article is licensed under a Creative Commons Attribution 4.0 International License, which permits use, sharing, adaptation, distribution and reproduction in any medium or format, as long as you give appropriate credit to the original author(s) and the source, provide a link to the Creative Commons licence, and indicate if changes were made. The images or other third party material in this article are included in the article's Creative Commons licence, unless indicated otherwise in a credit line to the material. If material is not included in the article's Creative Commons licence and your intended use is not permitted by statutory regulation or exceeds the permitted use, you will need to obtain permission directly from the copyright holder. To view a copy of this licence, visit http://creativecommons.org/licenses/by/4.0/.

\section{References}

Agnello, A. C., Bagard, M., van Hullebusch, E. D., Esposito, G., \& Huguenot, D. (2016). Comparative bioremediation of heavy metals and petroleum hydrocarbons co-contaminated soil by natural attenuation, phytoremediation, bioaugmentation and bioaugmentation-assisted phytoremediation. Science of the Total Environment, 563-564, 693-703. https://doi. org/10.1016/j.scitotenv.2015.10.061.

Alisi, C., Musella, R., Tasso, F., Ubaldi, C., Manzo, S., Cremisini, C., \& Sprocati, A. R. (2009). Bioremediation of diesel oil in a co-contaminated soil by bioaugmentation with a microbial formula tailored with native strains selected for heavy metals resistance. Science of the Total Environment, 407(8), 30243032. https://doi.org/10.1016/j.scitotenv.2009.01.011.

Alvarez, A., Saez, J. M., Costa, J. S. D., Colin, V. L., Fuentes, M. S., Cuozzo, S. A., Benimeli, C. S., Polti, M. A., \& Amoroso, M. J. (2017). Actinobacteria: Current research and perspectives for bioremediation of pesticides and heavy metals. Chemosphere, 166, 41-62. https://doi.org/10.1016/j. chemosphere.2016.09.070

Ashraf, M. A., Hussain, I., Rasheed, R., Iqbal, M., Riaz, M., \& Arif, M. S. (2017). Advances in microbe-assisted reclamation of heavy metal contaminated soils over the last decade: A review. Journal of Environmental Management, 198(1), 132-143. https://doi.org/10.1016/j.jenvman.2017.04.060.

Babu, A. G., Shea, P. J., Sudhakar, D., Jung, I. B., \& Oh, B. T. (2015). Potential use of Pseudomonas koreensis AGB-1 in association with Miscanthus sinensis to remediate heavy metal(loid)-contaminated mining site soil. Journal of Environmental Management, 151, 160-166. https:/doi. org/10.1016/j.jenvman.2014.12.045
Baćmaga, M., Kucharski, J., \& Wyszkowska, J. (2015). Microbial and enzymatic activity of soil contaminated with Azoxystrobin. Environmental Monitoring and Assessment, 187, 615. https://doi.org/10.1007/s10661-015-4827-5.

Bieganowski, A., Witkowska-Walczak, B., Gliński, J., Sokołowska, Z., Sławiński, C., Brzezińska, M., \& Włodarczyk, T. (2013). Database of Polish arable mineral soils: A review. International Agrophysics, 27(3), 335-350. https://doi.org/10.2478/intag-2013-0003.

Boros, E., Baćmaga, M., Kucharski, J., \& Wyszkowska, J. (2011). The usefulness of organic substances and plant growth in neutralizing the effects of zinc on the biochemical properties of soil. Fresenius Environmental Bulletin, 20(12), 31013109.

Borowik, A., Wyszkowska, J., Kucharski, J., Baćmaga, M., Boros-Lajszner, E., \& Tomkiel, M. (2014). Sensitivity of soil enzymes to excessive zinc concentrations. Journal of Elementology, 19(3), 637-648. https://doi.org/10.5601 /jelem.2014.19.2.456.

Borowik, A., Wyszkowska, J., \& Wyszkowski, M. (2017). Resistance of aerobic microorganisms and soil enzyme response to soil contamination with ekodiesel ultra fuel. Environmental Science and Pollution Research, 24, 24346 24363. https://doi.org/10.1007/s11356-017-0076-1.

Braud, A., Jézéquel, K., Vieille, E., Tritter, A., \& Lebeau, T. (2006). Changes in extractability of $\mathrm{Cr}$ and $\mathrm{Pb}$ in a polycontaminated soil after bioaugmentation with microbial producers of biosurfactants, organic acids and siderophores. Water, Air \& Soil Pollution, 6, 261-279. https://doi. org/10.1007/s11267-005-9022-1.

Bunt, J. S., \& Rovira, A. D. (1955). Microbiological studies of some subantarctic soils. Journal of Soil Science, 6, 119-128. https://doi.org/10.1111/j.1365-2389.1955.tb00836.x.

Cáliz, J., Montserrat, G., Martí, E., Sierra, J., Chung, A. P., Morais, P. V., \& Vila, X. (2013). Emerging resistant microbiota from an acidic soil exposed to toxicity of $\mathrm{Cr}, \mathrm{Cd}$ and $\mathrm{Pb}$ is mainly influenced by the bioavailability of these metals. Journal of Soils and Sediments, 13, 413-428. https://doi.org/10.1007 /s11368-012-0609-7.

Chanda, D., Sharma, G. D., Jha, D. K., \& Hijri, M. (2017). Tolerance of microorganisms in soil contaminated with trace metals: An overview. In P. Shukla (Ed.), Recent advances in applied microbiology (pp. 165-193). Springer: Singapore. https://doi.org/10.1007/978-981-10-5275-0_8.

Chibuike, G., \& Obiora, S. (2014). Heavy metal polluted soils: Effect on plants and bioremediation methods. Applied and Environmental Soil Science, 2014, 1-12. https://doi. org/10.1155/2014/752708.

Das, N. (2010). Recovery of precious metals through biosorption-A review. Hydrometallurgy, 103(1-4), 180 189. https://doi.org/10.1016/j.hydromet.2010.03.016.

De Leij, F. A. A. M., Whipps, J. M., \& Lynch, J. M. (1993). The use of colony development for the characterization of bacterial communities in soil and on roots. Microbial Ecology, 27, 81-97. https://doi.org/10.1007/BF00170116.

Donot, F., Fontana, A., Baccou, J., \& Schorr-Galindo, S. (2012). Microbial exopolysaccharides: Main examples of synthesis, excretion, genetics and extraction. Carbohydrate Polymers, 87, 951-962. https://doi.org/10.1016/j.carbpol.2011.08.083.

Emenike, C. U., Agamuthu, P., \& Fauziah, S. H. (2017). Sustainable remediation of heavy metal polluted soil: A 
biotechnical interaction with selected bacteria species. Journal of Geochemical Exploration, 182(Part B), 275278. https://doi.org/10.1016/j.gexplo.2016.10.002.

Fauziah, S. H., Agamuthu, P., Hashim, R., Izyani, A. K., \& Emenike, C. U. (2017). Assessing the bioaugmentation potentials of individual isolates from landfill on metal-polluted soil. Environmental Earth Science, 76, 401. https://doi. org/10.1007/s12665-017-6739-x.

Gupta, P., \& Diwan, B. (2017). Bacterial exopolysaccharide mediated heavy metal removal: A review on biosynthesis, mechanism and remediation strategies. Biotechnology Reports, 13, 58-71. https://doi.org/10.1016/j. btre.2016.12.006.

Gupta, V. K., Nayak, A., \& Agarwal, S. (2015). Bioadsorbents for remediation of heavy metals: Current status and their future prospects. Environmental Engineering Research, 20(1), 118. https://doi.org/10.4491/eer.2015.018.

Hafez, M. B., Fouad, A., \& El-Desouky, W. (2002). Accumulation of some metal ions on Bacillus licheniformis. J Radioanal Nucl Ch., 251, 249-252. https://doi.org/10.1023 /A:1014860125739.

Harris, D. C. (2006). Quantitative chemical analysis; Michelson Laboratory Chine Lake USA. 7th ed.; WH Freeman and Company: 1008 .

Hoseinzadeh, S., Shahabivand, S., \& Aliloo, A. A. (2017). Toxic metals accumulation in Trichoderma asperellum and T. harzianum. Microbiology, 86(6), 728-736. https://doi. org/10.1134/S0026261717060066.

Jayanthi, B., Emenike, C. U., Agamuthu, P., Simarani, K., Mohamad, S., \& Fauziah, S. H. (2016). Selected microbial diversity of contaminated landfill soil of Peninsular Malaysia and the behavior towards heavy metal exposure. Catena, 147, 25-31. https://doi.org/10.1016/j.catena.2016.06.033.

Khalid, S., Shahid, M., Niazi, N. K., Murtaza, B., Bibi, I., \& Dumat, C. (2017). A comparison of technologies for remediation of heavy metal contaminated soils. Journal of Geochemical Exploration, 182(B), 247-268. https://doi. org/10.1016/j.gexplo.2016.11.021.

Krantz-Rülcker, C., Allard, B., \& Schnürer, J. (1993). Interactions between a soil fungus, Trichoderma harzianum, and IIb metals-adsorption to mycelium and production of complexing metabolites. Biometals, 6, 223-230. https://doi. org/10.1007/BF00187759.

Kucharski, J., Wieczorek, K., \& Wyszkowska, J. (2011). Changes in the enzymatic activity in sandy loam soil exposed to zinc pressure. Journal of Elementology, 16(4), 577-589. https://doi.org/10.5601/jelem.2011.16.4.07.

Liu, G., Wang, J., Lu, X., Liu, X., Li, X., Ren, Y., Wang, J., \& Dong, L. (2018). Partitioning and geochemical fractions of heavy metals from geogenic and anthropogenic sources in various soil particle size fractions. Geoderma, 312, 104-113. https://doi.org/10.1016/j.geoderma.2017.10.013.

Ma, Y., Rajkumar, M., \& Freitas, H. (2009). Isolation and characterization of Ni mobilizing PGPB from serpentine soils and their potential in promoting plant growth and $\mathrm{Ni}$ accumulation by Brassica spp. Chemosphere, 75(6), 719-725. https://doi.org/10.1016/j.chemosphere.2009.01.056.

Machado, M. D., Soares, E. V., \& Soares, H. M. (2010). Removal of heavy metals using a brewer's yeast strain of Saccharomyces cerevisiae: Chemical speciation as a tool in the prediction and improving of treatment efficiency of real electroplating effluents. Journal of Hazardous Materials, $180,347-353$. https://doi.org/10.1016/j. jhazmat.2010.04.037.

Martin, J. (1950). Use of acid rose bengal and streptomycin in the plate method for estimating soil fungi. Soil Science, 69, 215233. https://doi.org/10.1097/00010694-195003000-00006.

Mesa, J., Rodríguez-Llorente, I. D., Pajuelo, E., Barcia-Piedras, J. M., Caviedes, M. A., Redondo-Gómez, S., \& MateosNaranjo, E. (2015). Moving closer towards restoration of contaminated estuaries: Bioaugmentation with autochthonous Rhizobacteria improves metal rhizoaccumulation in native Spartina maritima. Journal of Hazardous Materials, 300, 263-271. https://doi.org/10.1016/j. jhazmat.2015.07.006.

Mrozik, A., \& Piotrowska-Seget, Z. (2010). Bioaugmentation as a strategy for cleaning up of soils contaminated with aromatic compounds. Microbiological Research, 165(5), 363-375. https://doi.org/10.1016/j.micres.2009.08.001.

Navarro-Torre, S., Mateos-Naranjo, E., Caviedes, M. A., Pajuelo, E., \& Rodríguez-Llorente, I. D. (2016). Isolation of plantgrowth-promoting and metal-resistant cultivable bacteria from Arthrocnemum macrostachyum in the Odiel marshes with potential use in phytoremediation. Marine Pollution Bulletin, 110(1), 133-142. https://doi.org/10.1016/j. marpolbul.2016.06.070.

Navarro-Torre, S., Barcia-Piedras, J. M., Caviedes, M. A., Pajuelo, E., Redondo-Gómez, S., Rodríguez-Llorente, I. D., \& Mateos-Naranjo, E. (2017). Bioaugmentation with bacteria selected from the microbiome enhances Arthrocnemum macrostachyum metal accumulation and tolerance. Marine Pollution Bulletin, 117(1-2), 340-347. https://doi. org/10.1016/j.marpolbul.2017.02.008.

Ojuederie, O. B., \& Babalola, O. O. (2017). Microbial and plantassisted bioremediation of heavy metal polluted environments: A review. International Journal of Environmental Research Public Health, 14, 1504. https://doi.org/10.3390 /ijerph14121504.

Pani, T., Das, A., \& Osborne, J. W. (2017). Bioremoval of zinc and manganese by bacterial biofilm: A bioreactor-based approach. Journal of Photochemistry and Photobiology B, 175, 211-218. https://doi.org/10.1016/j.jphotobiol.2017.08.039.

Płociniczak, T., Kukla, M., Wątroba, R., \& Piotrowska-Seget, Z. (2013). The effect of soil bioaugmentation with strains of Pseudomonas on $\mathrm{Cd}, \mathrm{Zn}$ and $\mathrm{Cu}$ uptake by Sinapis alba $\mathrm{L}$. Chemosphere, 91(9), 1332-1337. https://doi.org/10.1016/j. chemosphere.2013.03.008.

Qu, J., Ren, G., Chen, B., Fan, J., \& Yong, E. (2011). Effects of lead and zinc mining contamination on bacterial community diversity and enzyme activiies of vicinal cropland. Environmental Monitoring and Assessment, 182, 597-606. https://doi.org/10.1007/s10661-011-1900-6.

Rojjanateeranaj, P., Sangthong, C., \& Prapagdee, B. (2017). Enhanced cadmium phytoremediation of Glycine max L. through bioaugmentation of cadmium-resistant bacteria assisted by biostimulation. Chemosphere, 185, 764-771. https://doi.org/10.1016/j.chemosphere.2017.07.074.

Sarathchandra, S. U., Burch, G., \& Cox, N. R. (1997). Growth patterns of bacterial communities in the rhizoplane and rhizosphere in white clover (Trifolium repens L.) and perennial ryegrass (Lolium perenne L.) in long-term pasture. Applied 
Soil Ecology, 6, 293-299. https://doi.org/10.1016/S09291393(97)00015-2.

Selvi, A., \& Aruliah, R. A. (2018). Statistical approach of zinc remediation using acidophilic bacterium via an integrated approach of bioleaching enhanced electrokinetic remediation (BEER) technology. Chemosphere, 207, 753-763. https://doi.org/10.1016/j.chemosphere.2018.05.144.

Simpson, D. R., Natraj, N. R., McInerney, M. J., \& Duncan, K. E. (2011). Biosurfactant-producing Bacillus are present in produced brines from Oklahoma oil reservoirs with a wide range of salinities. Applied Microbiology and Biotechnology, 91, 1083-1093. https://doi.org/10.1007/s00253-011-3326-z.

Sørensen, A., Lübeck, M., Lübeck, P. S., \& Ahring, B. K. (2013). Fungal beta-glucosidases: A bottleneck in industrial use of lignocellulosic materials. Biomolecules, 3(3), 612-631. https://doi.org/10.3390/biom3030612.

Statistica (data analysis software system), version 12.0, StatSoft Inc. (2014). Available at www.statsoft.com.

Strachel, R., Wyszkowska, J., \& Baćmaga, M. (2017). The role of compost in stabilizing the microbiological and biochemical properties of zinc-stressed soil. Water, Air \& Soil Pollution, 228, 349. https://doi.org/10.1007/s11270-017-3539-6.

Strachel, R., Wyszkowska, J., \& Baćmaga, M. (2018). An evaluation of the effectiveness of sorbents in the remediation of soil contaminated with zinc. Water Air and Soil Pollution, 229, 235. https://doi.org/10.1007/s11270-018-3882-2.

Su, S., Zeng, X., Bai, L., Jiang, X., \& Li, L. (2010). Bioaccumulation and biovolatilisation of pentavalent arsenic by Penicillin janthinellum, Fusarium oxysporum and Trichoderma asperellum under laboratory conditions. Current Microbiology, 61, 261. https://doi.org/10.1007 /s00284-010-9605-6.

Valentine, N. B., Bolton, H., Kingsley Jr., M. T., Drake, G. R., Balkwil, D. L., \& Plymale, A. E. (1996). Biosorption of cadmium, cobalt, nickel, and strontium by a Bacillus simplex strain isolated from the vadose zone. Journal of Industrial Microbiology and Biotechnology, 16, 189-196. https://doi. org/10.1007/BF01570003.

Wang, G. L., Wang, L., Chen, H. H., Shen, B., Li, S. P., \& Jiang, J. D. (2011). Lysobacter ruishenii sp. nov., a chlorothalonildegrading bacterium isolated from a longterm chlorothalonil-contaminated soil. International Journal of Systematic and Evolutionary Microbioog, 61, 674. https://doi.org/10.1099/ijs.0.020990-0.
Wang, T., Sun, H., Mao, H., Zhang, Y., Wang, C., Zhang, Z., Wang, B., \& Sun, L. (2014). The immobilization of heavy metals in soil by bioaugmentation of a UV-mutant Bacillus subtilis 38 assisted by NovoGro biostimulation and changes of soil microbial community. Journal of Hazardous Materials, 278, 483-490. https://doi.org/10.1016/j. jhazmat.2014.06.028.

Wieczorek, K., Wyszkowska, J., \& Kucharski, J. (2014). Influence of zinc, copper, nickel, cadmium and lead in soils on acid phosphatase activity. Fresenenius Environmental Bulletin, 23(1A), 274-284.

Wieczorek, K., Wyszkowska, J., \& Kucharski, J. (2015). Resistance of soil urease to soil contamination with zinc, copper, nickel, cadmium and lead. Fresenius Environmental Bulletin, 24(8), 2496-2504.

Wieczorek, K., Kucharski, J., \& Wyszkowska, J. (2017). Sensitivity of beta-glucosidase to soil contamination with zinc, copper, nickel, cadmium and lead. Fresenius Environmental Bulletin, 26(12A), 7658-7666.

Wyszkowska, J., Borowik, A., Kucharski, M., \& Kucharski, J. (2013). Effect of cadmium, copper and zinc on plants, soil microorganisms and soil enzymes. Journal of Elementology, 18(4), 769-796. https://doi.org/10.5601 /jelem.2013.18.4.455.

Wyszkowska, J., Boros-Lajszner, E., Borowik, A., Baćmaga, M., Kucharski, J., \& Tomkiel, M. (2016). Implication of zinc excess on soil health. Journal of Environmental Science and Health Part B, 51(5), 261-270. https://doi.org/10.1080 $/ 10934529.2015 .1128726$.

Wyszkowska, J., Boros-Lajszner, E., Borowik, A., Kucharski, J., Baćmaga, M., \& Tomkiel, M. (2017). Changes in the microbiological and biochemical properties of soil contaminated with zinc. Journal of Elementology, 22(2), 437-451. https://doi.org/10.5601/jelem.2016.21.2.1213.

Zhou, M., Liu, Y., Zeng, G., Li, X., Xu, W., \& Fan, T. (2007). Kinetic and equilibrium studies of $\mathrm{Cr}(\mathrm{VI})$ biosorption by dead Bacillus licheniformis biomass. World Journal of Microbiology and Biotechnology, 23, 43-48. https://doi. org/10.1007/s1 1274-006-9191-8.

Publisher's Note Springer Nature remains neutral with regard to jurisdictional claims in published maps and institutional affiliations. 